\title{
from 'Tell Tale Signs'
}

Janice Williamson

\section{Tiré de 'Tell Tale Signs'}

Dans cet extrait tiré de 'Tell Tale Signs', la voyageuse explore le paysage physique et mental de l'Alberta au moyend' une syntaxe saccadée, tandis qu' elle promène son regard des feux de déchets d'abattage au centre d'achat d'Edmonton ouest aux gratte-ciel d'Edmonton, et d'idylles et séductions si l'on peut dire. Elle nous montre comment elle pense par son corps tandis que son esprit examine rapidement le marbre des sols, cherchant des indices, recueillant des débris d'objets, indications d'un écrivain qui prend des notes. 

Face posed, fixed up by the door. Likeall but a few of the others she worked to enclose herself in the familiar. Our everyday echo chamber resounded: ASTONISHING LONGING, LOST HOPE, INCREDIBLE NOSTALGIA.

But this chorus, a history of connection, is not central to the story. Transplanted west, she reads Peterina to the Rescue. Unapologetic about her misery, she ignores all calls to courage: mountain climbing, homesteading, calf-breaking, jelly making, cowcatcher-riding frontierswomen possess something she does not. Prairie women stand up: frozen to sculpted stoicism season after season, mahogany-branched dogwood casts brave shadows across the snow white, grow leaf thick in spring. Uprooted and planted into this prairie garden, she imagines herself clematis, a high yellow note. Clinging sturdily to the back fence, narcissistic gold fades to autumn wisps of fruit fragile to darkness. Root-threatened bone-numb winter kill.

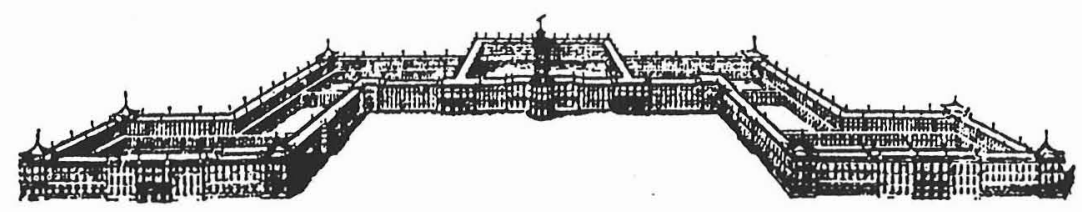

fig. 25

Quick silver, a fish, her mind darts here and there sucking at roots, pulling out tender white dream stems. From nightmares of loss and abandonment, stories tell too much of what she knows and doesn't know: stories about herself, by herself. 
NOW is now and she has no television. Unknown to her different soap opera women perform variations of the familiar under the same name. He, her husband, his children, his computers, his new brunette wife (the same name, can you believe it?) have moved back to Europe, bankrupt. She now lives in a more modest house, more remote city, divides her life into two overlapping categories of public / private: work / play. She won't stop writing endlessly about her work, her job, her desires, her body. Doubts surface: 'Will I forever suffer the slur of mustard rape seed across my being?' Haunted by the memory of Manitoba summers, she averts the eager colonial gaze southward from Toronto to New York.

A concerned colleague asks if she is undergoing a 'make-over,' in quotations, as though she is contagious. She considers trimming her bushy eyebrows, etc. Gazing dully across the parade of backyard garages, she contemplates removing herself to an imposing riverbank, a Wayne Gretzky twelfth or twentieth floor. Acres of bungalow lights twinkle towards the horizon, then switch off where the silent nothing of taiga begins.

fig. 26

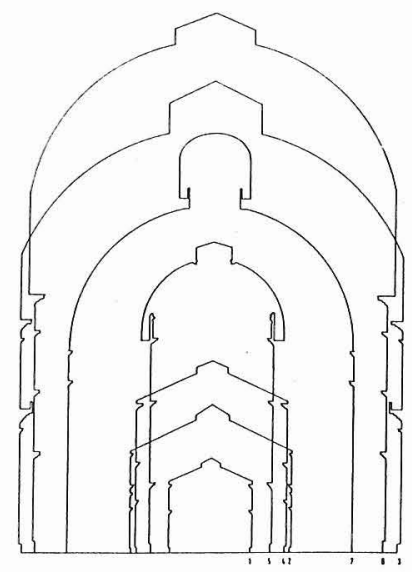

BIG as the big JESUS splashed across the side of the Calgary Trail grain elevator, the moon glides upward diminishing in diameter as it arcs across the city. She thinks of her body, of food, of fuel - of the future of her body and what's left of her mind. Always there is something she ought to be doing, something other than what she is doing, something she should have been doing, impeccably, already. 
Slip step, chassé round the room, zoom long look through snow ravine. Camera lens dog-like in debris, suburban detritus, hair now wind-swept, touch of gel smoothed to fuzz soft-focus edge. Cruise long look past war canoes; paddling backwards Paul Kane drifts the long river sometime after native women occasioned his words. Sometime after The Famous Canadian Writers in search of The Famous Canadian Explorers wrapped themselves in how many yards of The Famous Canadian Netting and set out on foot The Famous Canadian Players in The Famous Canadian North where The Famous Canadian Native Painters set up shop and missiles dove through spirit lines in among The Famous Canadian Location of Lac La Biche inhabited by The Famous Canadian Mothers (and largest muslim population per capita) who flow through The Famous Canadian Peace River, never known to have inspired same. Long look through wolf willow aspen clack clack poplar whittle-song in the air.

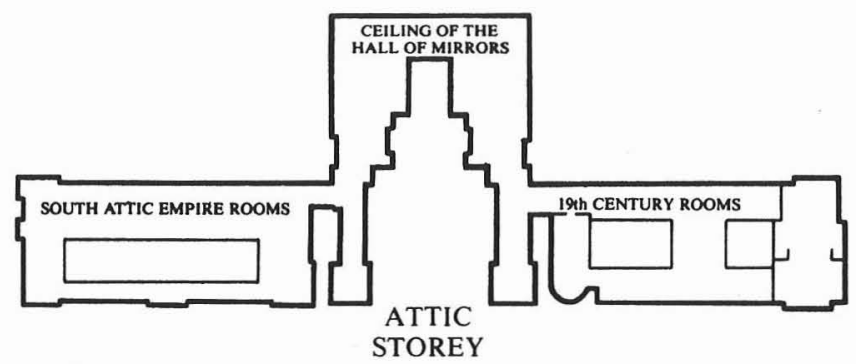

fig. 27

Shrovel shrovel, my bleary mud-coated look gets into the car, something about naked ladies on the radio all the way to West Edmonton Mall.... Drive drive, she said, all the time his wet nose pressed to the window. Neighbourhoods streakstucco livid with green underglass. 
(the writer shops till she flops

His kinetic sculpture is at the opposite end of the mall. She calls it (how thoughtless) the 'banal' region. No canals. No Hollywood pyrotechnics. No simulation of elsewhere: be here now at this water's edge at this large (larger) moment of history. 'Discover new continents of pleasure,' a perfumed Christopher Columbus intones beneath his giltedged Santa Maria, her polyethylene simulation of beached timber. On this chemical beach, large waves of pleasure await week-end guests: westward machines heave up surges of white-capped (reduced non-saline, six possible wave types all the/ way to surfing. height, you remind me) crests. None of this No peaco k tails strul under glass. No croissants. No pain au chocolat. No Europa Boulevard fake paintings duplicating every other fake painting every where else except China (you remind me) where fakery has its place in museums. In the east, the affront of duplication is diminished by skill our pleasure is in laboured calligraphic strokes. Here, Medieval Dungeons invite tourists to the dark side of history rewarding courage with Michael Jackson tickets. Sell signs of torture beside glas sed in cases of crown jewels: real. (Take my word for it).

fig. 28

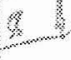

Later she thinks about the other side or her banal the knetic sculpture. Wooden blocks sound hard. Steet drumroll balls move circulareduce speed circumference drop through centre hole one by one, not quite slow untll - wateh - the final disappearanee. A caught liff fromand rising up forked metal fingers catch (just in the ) rise up and drop, through space. Ball (wood) lingers the length of an are rail past a fat man towards two one-eyed spider monkeys (once gain tunderglass) holding fingers to ears. Crash of cymbals. Time's up Moremuzak. No lingening while undertoo much colour (with the you) domed prairie blue sky dotted miniature yellowed golf balls catch a ide tomards a second foor named first. Our chartreuse lock step balances heels metallic click.

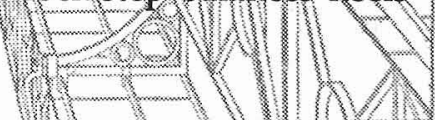


(the writer takes note

There are two things henotices: the skaters' pleasureand the kinetic sculpture. Not the monument to socialist realist men, their monstrous bronze biceps drilling through the centre of an Albertan earth. Sculptured bronze hands grip pipelines heading south: a toil larger than life. Inconspicuous dinosaurs list in shifting sands. He does not notice the hand-cuffed cussing New Orleans' prostitutes in plaster; the pair of woman's legs emerging from an upper storey window (her scream removed); the Mardi Gras travesties of the Pays Dogon. (This is not true. He mentions them in passing.) They do not notice in detail how the women behind the counter share gossip oblivious to whether or not the fountains dance hourly to Beethoven's Ninth.

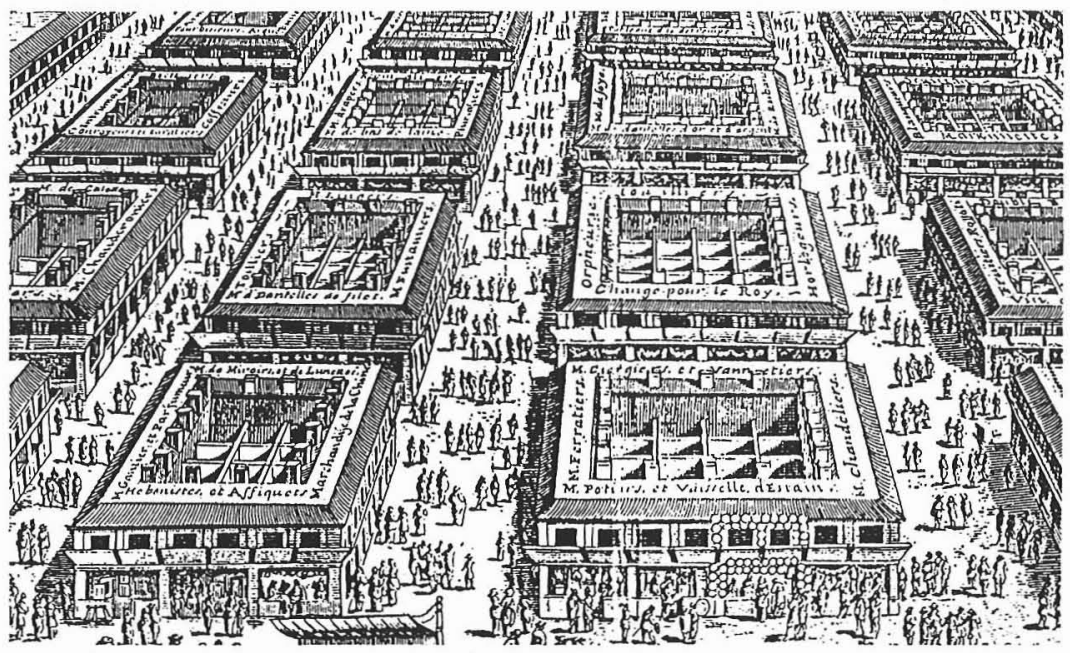

fig. 29

This is not a seduction. She assures him this is the case, though shecannot help the way she thinks through her body. Imagine this a compensation for the way her mind scurries along the marble floors, looks for clues, collects debris.... She thinks 'marble' - the cool touch baffling sound's babble only in so far as she and the woman across the mall look up to hear each other speak loud now. Pop song: the way you walk. 


\section{from 'Tell Tale Signs' · 93}

\section{(the epistolary romances}

Upstairs and down, they write their letters about the serious side of desire, its relation to production. 'How does one produce without desire?' Do they intend the question differently? Estelle flips through Woodward's Christmas Catalogue looking for vibrating apparatus to assist her writing's progress. Last season, The Bay sold out their vibrators before she could reach the store. 'A run on stiff necks?' she asked the clerk who smiled serenely, satisfied at her own bargain purchase.

The other woman's certain of her desire, matches cheek to cheek the full pressure of breasts inside woollen February sweaters. Outside nothing is happening. The world 'passes by.' Events dissolve between backyards. Magpies litter the white lawn; blue jay brothers play at diversion from the main drift. The world is passing by, beyond, she writes. Objects come into their own and begin to act only when we find ourselves familiar with their possibilities. But here there is a strangeness in the landscape: clipped/sculpted shapes across the street, bushes green with waiting.

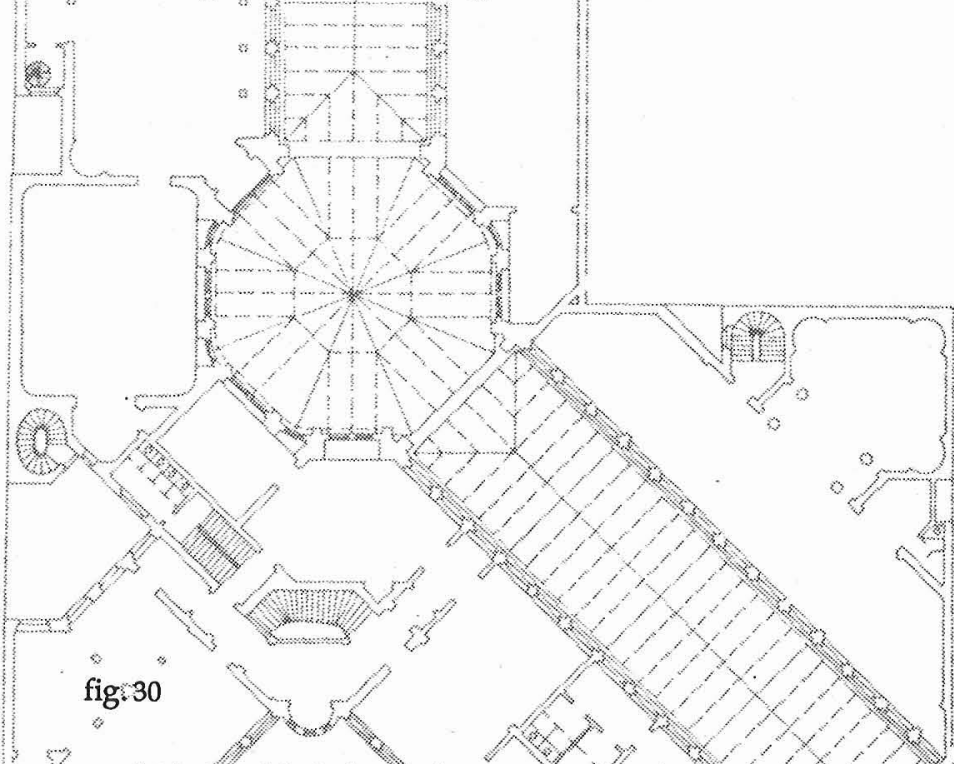

At least this is how they appear to the two women wriking, one wp, one down: serious, and because they remain so serious, they talkabout ambivalence as a sign of maturity. Estelle considers how unsettling passion can become when met with certain knowledge.

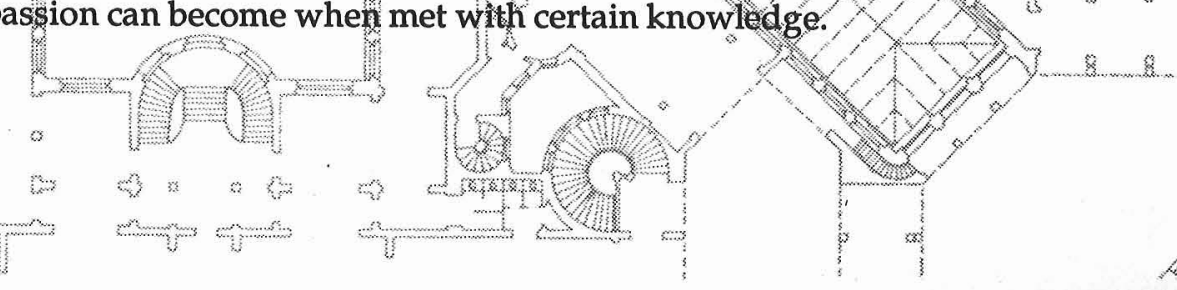


(the reader changes her tune

Inside, shoppers gather on the hour for the musical interlude. Parked outside the cowboy hats and lace-up dance dresses, flames bust through the fountain to the tunes of the Neapolitan Alessandro Scarlatti. Fitting, she muses, since this place like the maestro's own 'Singing City' Naples lies somewhere between Vesuvius and the sea. Her companion jots notes, mouthing his words while leaning on the large replica of a whale fitted out with a red velour thinking seat where a stalagmitic azygous uvula muscle might have protruded to beat about the intruders' heads had it ever appeared in living whales to perform anything more than sonic whistles. Leaning against the large replica of the whale (dull bronze finish) tense and professorial tones) Scarlatti's us for writing emil singable melodies wedded to clear tonally-centred hamony.' Reak (Dear Reader) calch the languid levicon, the longuage of romant Pages tum more quickly: feverish talk about new y articulated corpo real folds and stiraces nub logether, cross, unctoss (probably sill tarreta in symmetrical executiye maroon stipes). Catch the first notes

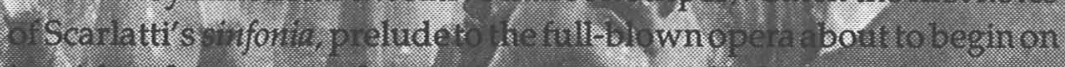

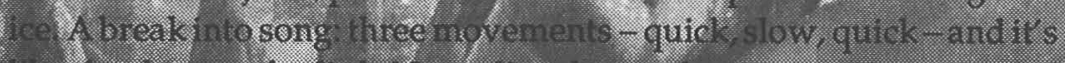

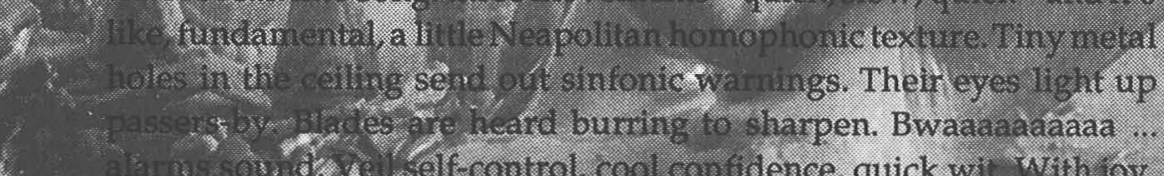

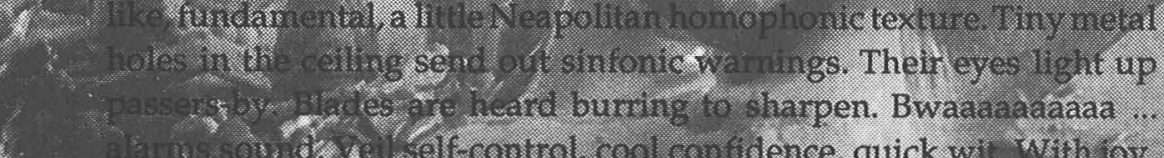

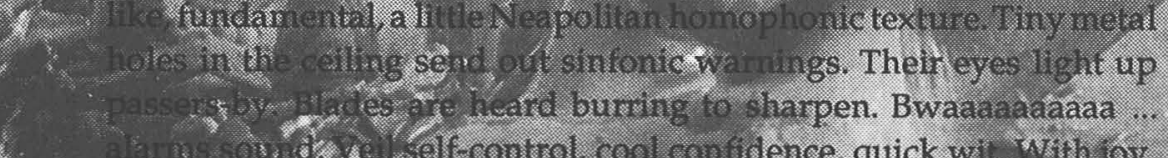

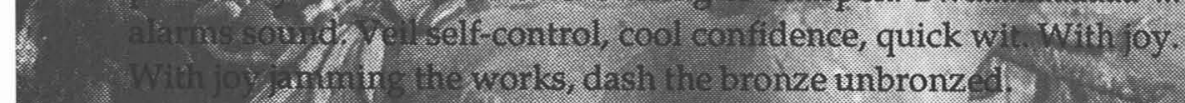

. 1

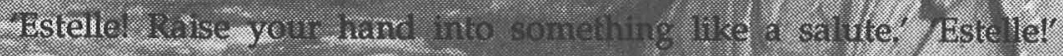
Tstelle? Ihe sky nothmg more than glassmeycel shell, la ta the way

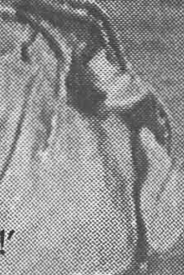
the sun glimis suratght wrough curves. So soft/(she says? Yes: 